\title{
Efikasi Afatinib dan Gefitinib pada Pasien Non-small Cell Lung Cancer EGFR Mutasi Positif: Tinjauan Sistematis
}

\author{
Seftika Sari ${ }^{1,2}$, Tri M. Andayani ${ }^{3}$, Dwi Endarti ${ }^{4}$, Kartika Widayati ${ }^{5}$ \\ ${ }^{1}$ Program Doktoral, Fakultas Farmasi, Universitas Gadjah Mada, Yogyakarta, Indonesia, \\ ${ }^{2}$ Sekolah Tinggi Ilmu Farmasi Riau, Pekanbaru, Indonesia, ${ }^{3}$ Bagian Farmakologi dan Farmasi \\ Klinik, Fakultas Farmasi, Universitas Gadjah Mada, Yogyakarta, Indonesia, ${ }^{4}$ Bagian \\ Farmasetik, Fakultas Farmasi, Universitas Gadjah Mada, Yogyakarta, Indonesia, ${ }^{5}$ Bagian \\ Kedokteran Internal, Subbagian Hematologi dan Onkologi Medik, Fakultas Kedokteran \\ Universitas Gadjah Mada-Rumah Sakit Dr. Sardjito, Yogyakarta, Indonesia
}

\begin{abstract}
Abstrak
Tyrosine kinase inhibitors (TKIs) telah direkomendasikan oleh National Comprehensive Cancer Network (NCCN) sebagai terapi lini pertama pada pasien non-small cell lung cancer (NSCLC) dengan mutasi EGFR, yaitu gefitinib (generasi pertama) dan afatinib (generasi kedua). Beberapa penelitian telah dilakukan terkait efikasi golongan TKIs ini, namun masih sedikit yang melakukan tinjauan sistematis (systematic review) secara khusus pada afatinib dan gefitinib. Systematic review ini bertujuan untuk memberikan gambaran secara komprehensif terkait efikasi afatinib dan gefitinib sebagai terapi lini pertama. Database yang digunakan untuk mengidentifikasi studi yang relevan yaitu Science Direct, PubMed dan Google Scholar. Penelitian ini terbatas pada penelitian randomized control trial, penggunaan afatinib dan gefitinib sebagai terapi lini pertama, penggunaan afatinib dan gefitinib secara monoterapi serta artikel yang menggunakan bahasa Inggris. Penelusuran berbasis data elektronik menghasilkan 2089 artikel; 48 artikel yang sudah sesuai dengan judul dan abstrak, namun hanya 8 artikel yang sesuai dengan inklusi yang ingin ditinjau. Secara umum efikasi afatinib dan gefitinib lebih unggul dibandingkan kemoterapi berbasis platinum, dapat dilihat dari progression free survival dari kedua obat ini yang lebih lama dibandingkan kemoterapi berbasis platinum. Walaupun nilai overall survival-nya tidak begitu lebih baik, afatinib dapat memperlambat perkembangan tumor lebih baik dibandingkan gefitinib. Efek samping yang sering terjadi pada afatinib dan gefitinib yaitu ruam dan diare, sedangkan neutropenia, mual, anemia sering terjadi pada penggunaan kemoterapi berbasis platinum. Afatinib dan gefitinib memberikan efikasi yang lebih baik dibandingkan kemoterapi berbasis platinum, namun afatinib memiliki efikasi yang lebih unggul dibandingkan gefitinib dalam pengobatan lini pertama pada pasien NSCLC dengan mutasi EGFR.
\end{abstract}

Kata kunci: Afatinib, efikasi, gefitinib, non-small cell lung cancer

\section{Afatinib and Gefitinib Efficacy on Non-small Cell Lung Cancer EGFR Mutation Patients: A Systematic Review}

\begin{abstract}
Tyrosine kinase inhibitors (TKIs) have been recommended by the National Comprehensive Cancer Networks (NCCN) as first-line therapy in non-small cell lung cancer (NSCLC) with EGFR mutation, namely gefitinib (first generation) and afatinib (second generation). Several studies have been conducted related to the efficacy of these TKIs, but few have conducted systematic reviews specifically afatinib and gefitinib. This systematic review aimed to provide a comprehensive overview of the efficacy of gefitinib and afatinib as first-line therapy. To identify the relevant studies, it used several databases such as Science Direct, PubMed, and Google Scholar. The review was limited to the randomized control trial study, the use of afatinib and gefitinib as first-line therapy, the use of afatinib and gefitinib as monotherapy, and articles written in the English language. An electronic data-based search identified 2089 articles; 48 articles matched the title and abstract, yet only 8 articles met the inclusion to be reviewed. In general, the efficacy of afatinib and gefitinib is more effective than platinum-based chemotherapy as showed that the progression-free survival of these medications is longer than platinum-based chemotherapy. Although the overall survival value is not better than platinum-based chemotherapy, afatinib inhibits the tumor growth better compared to gefitinib. Common side-effects in afatinib and gefitinib include rashes and diarrhea, while neutropenia, nausea, and anemia commonly occur in platinum-based chemotherapy. Afatinib and gefitinib offer better efficacy compared to platinum-based chemotherapy. Specifically, the afatinib has greater efficacy compared to gefitinib in first-line therapy for patient with NSCLC EGFR mutation.
\end{abstract}

Keyword: Afatinib, efficacy, gefitinib, non-small cell lung cancer

Korespondensi: Seftika Sari, MPH., Apt., Sekolah Tinggi Ilmu Farmasi Riau, Pekanbaru, Riau 28289, Indonesia, email: seftika1987.apt@gmail.com

Naskah diterima: 9 Februari 2019, Diterima untuk diterbitkan: 15 Juli 2019, Diterbitkan: 28 Desember 2019 


\section{Pendahuluan}

Kanker paru merupakan salah satu penyakit yang menjadi masalah kesehatan di dunia sebab menjadi salah satu penyebab kematian dari kejadian kanker di seluruh dunia. ${ }^{1}$ Jenis kanker paru yang sering terjadi adalah non small cell lung cancer (NSCLC) yakni sekitar $85 \%$ dari keseluruhan kanker paru, dan $80 \%$ dari kasus NSCLC merupakan pasien dengan stadium lanjut (stage IIIB/IV). ${ }^{2}$ Pada pasien NSCLC dengan stadium lanjut, kejadian mutasi epidermal growth factor receptor (EGFR) sering ditemukan. Terdapat 10\% hingga 15\% kasus pada pasien di negara barat dan sampai $50 \%$ pada pasien di negara Asia. ${ }^{3}$ National Comprehensive Cancer Network (NCCN) merekomendasikan EGFR-tyrosine kinase inhibitors (TKIs) sebagai lini pertama, seperti gefitinib, erlotinib (generasi pertama), serta afatinib (generasi kedua). ${ }^{4}$

TKIs generasi pertama (gefitinib dan erlotinib) secara reversible mengikat dan menghambat sinyal EGFR sedangkan TKIs generasi kedua (afatinib) dapat menghambat keluarga erythroblastosis oncogene B (ErbB) yang secara irreversible menghambat sinyal dari semua homodimer dan heterodimer dari reseptor famili ErbB (EGFR/ErbB1, HER2/ ErbB2, ErbB3 dan ErbB4). ${ }^{5,6}$ TKIs telah banyak digunakan sebagai pengobatan pada pasien NSCLC dengan mutasi EGFR dan lebih disukai jika dibandingkan kemoterapi lainnya. Hal ini kemungkinan disebabkan TKIs menunjukkan respon yang lebih tinggi, progression free survival (PFS) yang lebih lama, serta adanya peningkatan kualitas hidup, terutama pada gefitinib (generasi pertama) dan afatinib (generasi kedua). ${ }^{7}$

Beberapa penelitian fase III randomized control trial (RCT) terkait efikasi gefitinib dan afatinib telah banyak dilakukan, baik mengenai perbandingan efikasi gefitinib dan afatinib dengan agen kemoterapi berbasis platinum, maupun perbandingan efikasi antara sesama agen TKIs sebagai terapi lini pertama pada pasien NSCLC dengan mutasi EGFR. Penelitian sebelumnya, baik RCT maupun systematic review, lebih banyak memberikan gambaran mengenai efikasi semua golongan TKIs dan masih sedikit yang menggambarkan secara khusus mengenai efikasi dari kedua obat ini (afatinib dan gefitinib). ${ }^{7,8}$ Penelitian ini bertujuan untuk memberi gambaran yang lebih komprehensif terkait efikasi afatinib dan gefitinib sebagai terapi lini pertama.

\section{Metode}

Pencarian literatur dilakukan di PubMed, Science Direct dan database Google Scholar untuk mengidentifikasi semua artikel yang berkaitan dengan efikasi dari gefitinib dan afatinib sebagai terapi lini pertama yang digunakan pasien NSCLC dengan mutasi EGFR. Pencarian literatur dilakukan dengan menggunakan istilah/kata kunci dan strategi sebagai berikut: "efficacy" AND "safety" AND "gefitinib" AND "non-small cell lung cancer" AND "EGFR mutation positive". Pemilihan jangka waktu tahun terbit artikel dibatasi dari tahun 2008 sampai 2018.

Kriteria inklusi pada review ini yaitu: (1) Penelitian randomized control trial (RCT); (2) Penelitian yang menjelaskan tentang gefitinib dan afatinib sebagai terapi lini pertama; (3) Penelitian mengenai penggunaan gefitinib dan afatinib secara monoterapi; serta (4) Artikel yang menggunakan bahasa Inggris, sedangkan kriteria eksklusi pada review ini yaitu: (1) Penelitian berjenis tinjauan sistematis dan meta-analisis; (2) Penelitian yang tidak tersedia teks lengkapnya (baik dalam bentuk abstrak atau prosiding); dan (3) Penelitian yang diuji dengan plasebo. Kualitas penelitian dinilai menggunakan skala Jadad yang terdiri dari skala lima poin. Skor 1 atau 2 poin dianggap kualitas rendah dan skor 3-5 poin dianggap berkualitas tinggi. Penilaian dilakukan terkait apakah penelitian menggunakan percobaan 


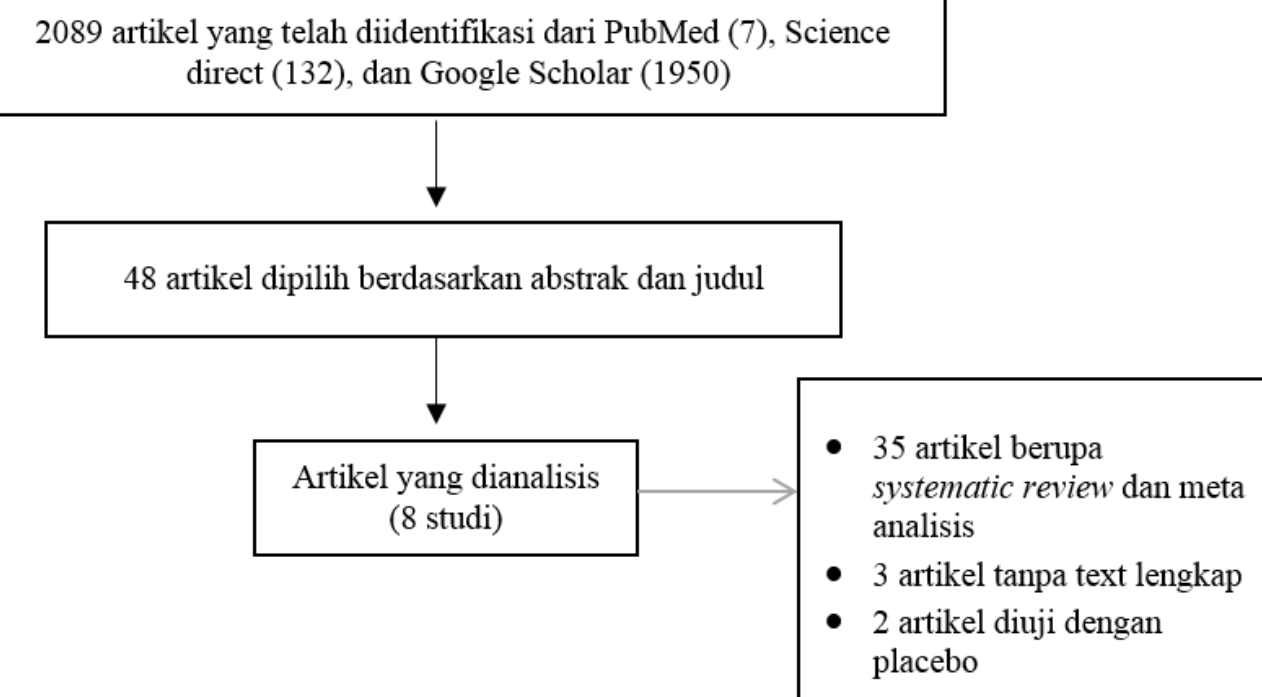

\section{Gambar 1 Diagram PRISMA}

acak, apakah peneliti memberikan gambaran pada metode pengacakan, apakah percobaan adalah double blind, apakah metode blinding digambarkan secara cukup rinci, dan apakah penarikan dilaporkan. ${ }^{9}$

Data lalu diekstraksi secara independen dengan menggunakan formulir yang standar untuk menggabungkan data-data beberapa penelitian yang sudah diseleksi. Data yang diekstraksi meliputi: penulis pertama, tahun publikasi, jumlah pasien, pengobatan, metode, tipe mutasi EGFR, median PFS, median overall survival (OS), dan efek samping.

\section{Hasil}

Hasil pencarian artikel

Langkah-langkah pencarian artikel untuk review ini disajikan dalam diagram PRISMA pada Gambar 1. Jumlah keseluruhan artikel yang telah teridentifikasi dari database yang digunakan yakni sebanyak 2089 artikel yang diperoleh dari Pubmed (7 artikel), Science Direct (132 artikel), dan Google Scholar (1950 artikel). Judul dan abstrak dari 2089 telah diidentifikasi secara independen dinilai oleh empat penulis, terdapat 48 artikel yang sesuai berdasarkan judul dan abstrak (40 artikel dikeluarkan dari pencarian disebabkan tidak sesuai dengan kriteria inklusi dan eksklusi). Sebanyak 8 artikel diperoleh untuk dilakukan review, dan semua artikel memiki skor 3-5 poin (kualitas tinggi).

Karakteristik penelitian

Artikel yang dilakukan analisis dalam review ini adalah penelitian yang telah dilakukan di beberapa negara, antara lain Korea Selatan, Singapura, Australia, Cina, Hongkong, Kanada, Taiwan, Perancis, Swedia, Inggris, Jerman, Spanyol, Thailand, India, Jepang, Republik Korea, Tokyo dan Indonesia, dan seluruhnya merupakan penelitian RCT.

Gefitinib dibandingkan dengan kemoterapi berbasis platinum

Terdapat 5 penelitian terkait efikasi gefitinib sebagai terapi lini pertama yang dibandingkan dengan kemoterapi berbasis platinum seperti dapat dilihat pada Tabel 1. Pada penelitian IRESSA Pan-Asia Study (IPASS), gefitinib dan kombinasi karboplatin dengan paklitaksel mempunyai PFS 24,9\% (gefitinib) dan 6,7\% (karboplatin dan paklitaksel), serta OS 18,8 bulan (gefitinib) dan 17,4 bulan (karboplatin dan paklitaksel). ${ }^{10}$ Penelitian WJTOG3405 
juga menunjukkan PFS gefitinib $(9,2$ bulan) lebih lama dibandingkan kombinasi sisplatin dan docetaksel (6,3 bulan), akan tetapi OS gefitinib tidak lebih baik jika dibandingkan dengan kemoterapi berbasis platinum, yaitu 36 bulan (gefitinib) dan 39 bulan (sisplatin dan docetaksel). ${ }^{11}$ Pada hasil penelitian FirstSIGNAL, nilai OS dari gefitinib tidak lebih unggul jika dibandingkan gemsitabin dengan sisplatin pada pasien yang tidak pernah merokok yaitu 22,3 bulan (gefitinib) dan 22,9 bulan (gemsitabin dan sisplatin). ${ }^{12}$ Penelitian NEJ002 menunjukkan PFS dan OS gefitinib lebih baik dibandingkan karboplatin dengan paklitaksel, yaitu 10,8 bulan (gefitinib) dan 5,4 bulan (karboplatin dan paklitaksel) untuk PFS dan 27,7 bulan (gefitinib) dan 26,6 bulan (karboplatin dan paklitaksel) untuk OS. ${ }^{13}$ Pada hasil studi fase III RCT yang meneliti tentang perbandingan antara gefitinib dengan pemetreksed dan karboplatin, PFS gefitinib lebih baik dibandingkan kemoterapi berbasis platinum ( 8,4 bulan dibandingkan 5,6 bulan), namun tidak begitu baik pada OS (18 bulan dibandingkan 22,6 bulan). ${ }^{14}$

Afatinib dibandingkan dengan kemoterapi berbasis platinum

Perbandingan antara efikasi afatinib dengan kemoterapi berbasis platinum sebagai terapi lini pertama tertera pada Tabel 1. Penelitian Lux-Lung 6 menunjukkan bahwa afatinib lebih unggul jika dibandingkan kemoterapi berbasis platinum. PFS afatinib lebih unggul dibandingkan gemsitabin dengan sisplatin (11 bulan dibandingkan 5,6 bulan), namun OS afatinib (22,1 bulan) tidak lebih unggul dibandingkan kombinasi gemsitabin dengan sisplatin (22,2 bulan). ${ }^{15}$

Gefitinib dibandingkan dengan afatinib Penelitian Lux-Lung 7 memberikan gambaran tentang efikasi afatinib dibandingkan dengan gefitinib. Penelitian ini menunjukkan bahwa PFS afatinib (11 bulan) lebih baik dibanding gefitinib (10,9 bulan). ${ }^{16}$ OS afatinib $(27,9$ bulan) juga lebih baik dibandingkan gefitinib ( 24,5 bulan), meskipun perbedaannya tidak signifikan $(\mathrm{p}=0,2580) .{ }^{17}$

Profil keamanan dan efek samping

Profil efek samping pada gefitinib secara umum tertera pada Tabel 1. Efek samping yang sering terjadi pada penggunaan gefitinib umumnya ruam kulit $(85,06 \%)$, diare $(54 \%)$, peningkatan aminotransferase hati $(70,1 \%)$, dan efek samping yang sering menyebabkan kematian yaitu penyakit paru interstitial $(1,3 \%) \cdot{ }^{10-12}$ Efek samping yang paling sering terjadi pada kemoterapi berbasis platinum adalah mual $(95,4 \%)$, neutropenia $(92,04 \%)$, anemia $(90,08 \%)$, dan neurotoksik $(69,9 \%),{ }^{10,11}$ sedangkan efek samping penggunaan afatinib yang sering terjadi adalah diare $13 \%$, ruam atau jerawat $(9 \%) .{ }^{16}$

\section{Pembahasan}

Afatinib dan gefitinib merupakan EGFRTKIs yang telah direkomendasikan NCCN sebagai terapi lini pertama untuk pengobatan NSCLC dengan mutasi EGFR. ${ }^{4}$ Hal ini dapat dilihat dari hasil perbandingan efikasi afatinib dan gefitinib dengan kemoterapi berbasis platinum. Penilaian efikasi pada penelitian dilakukan dengan melihat PFS (waktu pada kondisi awal terdiagnosisnya penyakit sampai terjadinya perkembangan atau keparahan pada penyakit) dan OS (waktu pada kondisi awal terdiagnosisnya penyakit sampai terjadi kematian). Dari 8 penelitian yang dilakukan review, secara umum diketahui bahwa afatinib dan gefitinib memiliki PFS yang lebih lama dibandingkan kemoterapi berbasis platinum, meskipun nilai OS-nya tidak lebih unggul dibandingkan kemoterapi berbasis platinum.

Gefitinib memiliki PFS yang lebih baik dari kemoterapi pada penelitian WJTOG3405 di Jepang, hal ini disebabkan PFS dapat dipengaruhi oleh jadwal kunjungan klinik dan 
Tabel 1 Ringkasan Hasil Penelitian (Data Ekstraksi)

\begin{tabular}{|c|c|c|c|c|c|c|c|c|c|c|}
\hline No. & $\begin{array}{l}\text { Penulis } \\
\text { dan } \\
\text { Tahun }\end{array}$ & Negara & $\begin{array}{c}\text { Pasien } \\
\text { (n) }\end{array}$ & Pengobatan & Metode & Mutasi EGFR & $\begin{array}{c}\text { Median } \\
\text { PFS }\end{array}$ & $\begin{array}{l}\text { Median } \\
\text { OS }\end{array}$ & Efek Samping & $\begin{array}{l}\text { Skor } \\
\text { Jadad }\end{array}$ \\
\hline \multirow[t]{2}{*}{1} & \multirow[t]{2}{*}{$\begin{array}{l}\text { Wu et al., } \\
2014\end{array}$} & \multirow[t]{2}{*}{ Jepang } & 242 & $\begin{array}{l}\text { Afatinib } \\
(40 \mathrm{mg} / \text { hari })\end{array}$ & \multirow[t]{2}{*}{$\begin{array}{l}\text { Randomized } \\
\text { control trial } \\
\text { (Lux-Lung 6) }\end{array}$} & \multirow[t]{2}{*}{$\begin{array}{l}\text { Exon } 19 \text { deletions, } \\
\text { Leu858Arg dan } \\
\text { mutasi lainnya }\end{array}$} & $\begin{array}{c}11 \\
\text { bulan }\end{array}$ & $\begin{array}{c}22,1 \\
\text { bulan }\end{array}$ & $\begin{array}{l}\text { Ruam atau jerawat } \\
(14,6 \% \text { dari } 239 \\
\text { pasien), diare }(5,4 \%) \\
\text { dan stomatitis atau } \\
\text { mucositis }(5.4 \%)\end{array}$ & \multirow[t]{2}{*}{4} \\
\hline & & & 122 & $\begin{array}{l}\text { Gemcitabine } \\
\left(1000 \mathrm{mg} / \mathrm{m}^{2}\right) \\
\text { dan cisplatin } \\
\left(75 \mathrm{mg} / \mathrm{m}^{2}\right)\end{array}$ & & & $\begin{array}{c}5,6 \\
\text { bulan }\end{array}$ & $\begin{array}{c}22,2 \\
\text { bulan }\end{array}$ & $\begin{array}{l}\text { Neutropenia }(26,5 \% \\
\text { dari } 113 \text { pasien }), \\
\text { muntah }(19,5 \%) \text {, dan } \\
\text { leukopenia }(15,0 \%)\end{array}$ & \\
\hline \multirow[t]{2}{*}{2} & \multirow[t]{2}{*}{$\begin{array}{l}\text { Park et al., } \\
2016\end{array}$} & $\begin{array}{l}\text { Korea Selatan, } \\
\text { Singapura, } \\
\text { Australia, China, }\end{array}$ & 160 & $\begin{array}{l}\text { Afatinib } \\
(40 \mathrm{mg} / \text { hari })\end{array}$ & \multirow[t]{2}{*}{$\begin{array}{l}\text { Randomized } \\
\text { control trial } \\
\text { (Lux-Lung 7) }\end{array}$} & \multirow[t]{2}{*}{$\begin{array}{l}\text { Exon } 19 \text { deletions, } \\
\text { Leu858Arg dan } \\
\text { mutasI lainnya }\end{array}$} & $\begin{array}{c}11 \\
\text { bulan }\end{array}$ & & $\begin{array}{l}\text { Diare }(13 \% \text { dari } 160 \\
\text { pasien }), \text { ruam atau } \\
\text { jerawat }(9 \%) \text {. }\end{array}$ & \multirow[t]{2}{*}{5} \\
\hline & & $\begin{array}{l}\text { Hongkong, } \\
\text { Canada, Taiwan, } \\
\text { Perancis, } \\
\text { Sweden, Inggris, } \\
\text { Jerman, Spanyol }\end{array}$ & 159 & $\begin{array}{l}\text { Gefitinib } \\
(250 \mathrm{mg} / \mathrm{hari})\end{array}$ & & & $\begin{array}{c}10,9 \\
\text { bulan }\end{array}$ & & $\begin{array}{l}\text { Diare }(1 \% \text { dari } 159 \\
\text { pasien }), \text { ruam atau } \\
\text { jerawat }(3 \%) \text {, dan } \\
\text { peningkatan enzim hati } \\
(9 \%)\end{array}$ & \\
\hline \multirow[t]{2}{*}{3} & \multirow[t]{2}{*}{$\begin{array}{l}\text { Arez et al., } \\
2017\end{array}$} & $\begin{array}{l}\text { Korea Selatan, } \\
\text { Singapura, } \\
\text { Australia, China, } \\
\text { Hongkong, }\end{array}$ & 146 & $\begin{array}{l}\text { Afatinib } \\
(40 \mathrm{mg} / \text { hari })\end{array}$ & \multirow[t]{2}{*}{$\begin{array}{l}\text { Randomized } \\
\text { control trial } \\
\text { (Lux-Lung 7) }\end{array}$} & \multirow[t]{2}{*}{$\begin{array}{l}\text { Exon } 19 \text { deletions, } \\
\text { Leu858Arg dan } \\
\text { mutasi lainnya }\end{array}$} & & $\begin{array}{c}27,9 \\
\text { bulan }\end{array}$ & $\begin{array}{l}\text { Diare }(13,1 \%), \text { ruam } \\
\text { atau jerawat }(9,4 \%) \text {, } \\
\text { kelelahan }(5,6 \%)\end{array}$ & \multirow[t]{2}{*}{3} \\
\hline & & $\begin{array}{l}\text { Canada, Taiwan, } \\
\text { Perancis, } \\
\text { Sweden, Inggris, } \\
\text { Jerman, Spanyol }\end{array}$ & 151 & $\begin{array}{l}\text { Gefitinib } \\
(250 \mathrm{mg} / \mathrm{hari})\end{array}$ & & & & $\begin{array}{c}24,5 \\
\text { bulan }\end{array}$ & $\begin{array}{l}\text { Diare }(1,3 \%), \text { ruam } \\
\text { atau jerawat }(3,1 \%), \\
\text { peningkatan aspartate } \\
\text { aminotransferase } \\
(2,5 \%), \text { penyakit paru } \\
\text { interstial }(1,9 \%)\end{array}$ & \\
\hline
\end{tabular}




\section{Tabel 1 Ringkasan Hasil Penelitian (Data Ekstraksi) (Tabel Lanjutan)}

\begin{tabular}{|c|c|c|c|c|c|c|c|c|c|c|}
\hline No. & $\begin{array}{c}\text { Penulis } \\
\text { dan Tahun }\end{array}$ & Negara & $\begin{array}{l}\text { Pasien } \\
\text { (n) }\end{array}$ & Pengobatan & Metode & Mutasi EGFR & $\begin{array}{l}\text { Median } \\
\text { PFS }\end{array}$ & $\begin{array}{l}\text { Median } \\
\text { OS }\end{array}$ & Efek Samping & $\begin{array}{l}\text { Skor } \\
\text { Jadad }\end{array}$ \\
\hline \multirow[t]{2}{*}{4} & $\begin{array}{l}\text { Mok et al., } \\
2009\end{array}$ & $\begin{array}{c}\text { China, } \\
\text { Hongkong, } \\
\text { Thailand, } \\
\text { Taiwan, Tokyo, } \\
\text { Indonesia, } \\
\text { Inggris }\end{array}$ & 607 & $\begin{array}{l}\text { Gefitinib } \\
(250 \mathrm{mg} / \text { hari })\end{array}$ & $\begin{array}{l}\text { Randomized } \\
\text { control trial } \\
\text { (IPASS) }\end{array}$ & $\begin{array}{l}\text { Exon } 19 \text { deletions, } \\
\text { exon } 21 \text { (L858R), } \\
\text { exon } 20 \text { (T790M) } \\
\text { dan mutasi lainnya }\end{array}$ & $\begin{array}{c}5,7 \\
\text { bulan } \\
\text { atau } \\
24,9 \% \\
(12 \\
\text { bulan) }\end{array}$ & $\begin{array}{c}18,8 \\
\text { bulan }\end{array}$ & $\begin{array}{l}\text { Ruam atau jerawat } \\
(66,2 \%) \text {, diare }(46,6 \%)\end{array}$ & 5 \\
\hline & & & 589 & $\begin{array}{l}\text { Karboplatin } \\
(5 \text { atau } 6 \mathrm{mg} / \mathrm{mL} \\
\text { per menit (AUC } \\
5 \text { atau } 6)) \text { dan } \\
\text { paklitaksel } \\
\left(200 \mathrm{mg} / \mathrm{m}^{2}\right)\end{array}$ & & & $\begin{array}{c}5,8 \\
\text { bulan } \\
\text { atau } \\
6,7 \% \\
(12 \\
\text { bulan) }\end{array}$ & $\begin{array}{c}17,4 \\
\text { bulan }\end{array}$ & $\begin{array}{l}\text { Neurotoksik }(69,9 \%) \text {, } \\
\text { neutropenia }(67,1 \%), \\
\text { alopecia }(58,4 \%)\end{array}$ & \\
\hline 5 & $\begin{array}{l}\text { Mitsudomi } \\
\text { et al., } 2010\end{array}$ & Jepang & 87 & $\begin{array}{l}\text { Gefitinib } \\
(250 \mathrm{mg} / \text { hari })\end{array}$ & $\begin{array}{l}\text { Randomized } \\
\text { control trial } \\
\text { (WJTOG3405) }\end{array}$ & $\begin{array}{l}\text { Exon } 19 \text { deletions, } \\
\text { exon } 21 \text { (L858R) }\end{array}$ & $\begin{array}{c}9,2 \\
\text { bulan }\end{array}$ & $\begin{array}{c}36 \\
\text { bulan }\end{array}$ & $\begin{array}{l}\text { Ruam kulit }(85,06 \%), \\
\text { AST }(70,1 \%), \text { ALT } \\
(70,1 \%), \text { kulit kering } \\
(54 \%) \text {, diare }(54 \%), \\
\text { kelelahan }(39,1 \%), \\
\text { paronychia }(32,2 \%), \\
\text { stomatitis/sariawan } \\
(21,8 \%), \text { mual } \\
(17,24 \%), \text { konstipasi } \\
(16,09 \%) \text {, alopecia } \\
(9,2 \%), \text { gangguan } \\
\text { sensorik }(8,04 \%), \\
\text { leukositopenia }(14,94 \%), \\
\text { trombositopenia } \\
(8,04 \%), \text { neutropenia } \\
(8,04 \%), \text { anemia }(37,9 \%)\end{array}$ & 4 \\
\hline
\end{tabular}


Tabel 1 Ringkasan Hasil Penelitian (Data Ekstraksi) (Tabel Lanjutan)

\begin{tabular}{|c|c|c|c|c|c|c|c|c|c|c|}
\hline No. & $\begin{array}{l}\text { Penulis } \\
\text { dan } \\
\text { Tahun }\end{array}$ & Negara & $\begin{array}{l}\text { Pasien } \\
\text { (n) }\end{array}$ & Pengobatan & Metode & Mutasi EGFR & $\begin{array}{l}\text { Median } \\
\text { PFS }\end{array}$ & $\begin{array}{l}\text { Median } \\
\text { OS }\end{array}$ & Efek Samping & $\begin{array}{l}\text { Skor } \\
\text { Jadad }\end{array}$ \\
\hline & & & 88 & $\begin{array}{l}\text { Cisplatin } \\
\left(80 \mathrm{mg} / \mathrm{m}^{2}\right) \text { dan } \\
\text { docetaksel } \\
\left(60 \mathrm{mg} / \mathrm{m}^{2}\right)\end{array}$ & & & $\begin{array}{c}6,3 \\
\text { bulan }\end{array}$ & $\begin{array}{c}39 \\
\text { bulan }\end{array}$ & $\begin{array}{l}\text { Ruam kulit }(7,95 \%), \\
\text { AST }(19,5 \%), \text { ALT } \\
(40,2 \%), \text { kulit kering } \\
(3,44 \%) \text {, diare }(40.23 \%), \\
\text { kelelahan }(83,9 \%), \\
\text { paronychia }(1,15 \%), \\
\text { stomatitis/sariawan } \\
(14,94 \%), \text { mual } \\
(95,4 \%), \text { konstipasi } \\
(44,83 \%) \text {, alopecia } \\
(77,01 \%) \text {, gangguan } \\
\text { sensorik (26,43\%), } \\
\text { leukositopenia }(94,25 \%), \\
\text { trombositopenia } \\
(32,95 \%), \text { neutropenia } \\
(92,04 \%), \text { anemia } \\
(90,8 \%)\end{array}$ & \\
\hline \multirow[t]{2}{*}{6} & $\begin{array}{l}\text { Han et al., } \\
2013\end{array}$ & $\begin{array}{c}\text { Republik } \\
\text { Korea }\end{array}$ & 159 & $\begin{array}{l}\text { Gefitinib } \\
(250 \mathrm{mg} / \text { hari })\end{array}$ & $\begin{array}{l}\text { Randomized } \\
\text { control trial } \\
\text { (First- } \\
\text { SIGNAL) }\end{array}$ & $\begin{array}{l}\text { Exon } 19 \text { deletions, } \\
\text { exon } 21 \text { (L858R) }\end{array}$ & $\begin{array}{c}5,8 \\
\text { bulan }\end{array}$ & $\begin{array}{l}22,3 \\
\text { bulan }\end{array}$ & $\begin{array}{l}\text { Ruam kulit dan } \\
\text { peningkatan enzim } \\
\text { hati, dan penyakit paru } \\
\text { interstial }(1,3 \%) \text {. }\end{array}$ & 4 \\
\hline & & & 150 & $\begin{array}{l}\text { Gemcitabine } \\
\left(1,250 \mathrm{mg} / \mathrm{m}^{2}\right) \\
\text { dan cisplatin } \\
80 \mathrm{mg} / \mathrm{m}^{2}\end{array}$ & & & $\begin{array}{c}6,4 \\
\text { bulan }\end{array}$ & $\begin{array}{l}22,9 \\
\text { bulan }\end{array}$ & $\begin{array}{l}\text { Toksisitas hematologi, } \\
\text { kelelahan, mual atau } \\
\text { muntah, dan alopecia }\end{array}$ & \\
\hline \multirow[t]{2}{*}{7} & $\begin{array}{l}\text { Inoue } e t \\
\text { al., } 2013\end{array}$ & Jepang & $\begin{array}{c}228 \\
\text { (total } \\
\text { pasien) }\end{array}$ & $\begin{array}{l}\text { Gefitinib } \\
(250 \mathrm{mg} / \text { hari })\end{array}$ & $\begin{array}{l}\text { Randomized } \\
\text { control trial } \\
\text { (NEJ002) }\end{array}$ & & $\begin{array}{c}10,8 \\
\text { bulan }\end{array}$ & $\begin{array}{l}27,7 \\
\text { bulan }\end{array}$ & $\begin{array}{l}\text { Ruam kulit, diare dan } \\
\text { penyakit interstial paru }\end{array}$ & 5 \\
\hline & & & & $\begin{array}{l}\text { Karboplatin } \\
\text { (AUC 6) dan } \\
\text { paclitaksel } \\
\left(200 \mathrm{mg} / \mathrm{m}^{2}\right)\end{array}$ & & & $\begin{array}{c}5,4 \\
\text { bulan }\end{array}$ & $\begin{array}{l}26,6 \\
\text { bulan }\end{array}$ & $\begin{array}{l}\text { Hilang nafsu makan, } \\
\text { neuropati sensorik, dan } \\
\text { myelotoksisitas }\end{array}$ & \\
\hline
\end{tabular}




\section{Tabel 1 Ringkasan Hasil Penelitian (Data Ekstraksi) (Tabel Lanjutan)}

\begin{tabular}{|c|c|c|c|c|c|c|c|c|c|c|}
\hline No. & $\begin{array}{l}\text { Penulis } \\
\text { dan } \\
\text { Tahun }\end{array}$ & Negara & $\begin{array}{l}\text { Pasien } \\
\text { (n) }\end{array}$ & Pengobatan & Metode & Mutasi EGFR & $\begin{array}{l}\text { Median } \\
\text { PFS }\end{array}$ & $\begin{array}{l}\text { Median } \\
\text { OS }\end{array}$ & Efek Samping & $\begin{array}{l}\text { Skor } \\
\text { Jadad }\end{array}$ \\
\hline \multirow[t]{2}{*}{8} & $\begin{array}{l}\text { Patil et al., } \\
2017\end{array}$ & India & 145 & $\begin{array}{l}\text { Gefitinib } \\
(250 \mathrm{mg} / \mathrm{hari})\end{array}$ & $\begin{array}{l}\text { A phase III } \\
\text { randomized } \\
\text { controlled trial }\end{array}$ & $\begin{array}{l}\text { Exon } 18 \text { (G719C } \\
\text { point mutation), } \\
\text { exon } 19 \text { deletions, } \\
\text { exon } 21 \text { (L858R) }\end{array}$ & $\begin{array}{c}8,4 \\
\text { bulan }\end{array}$ & $\begin{array}{c}18 \\
\text { bulan }\end{array}$ & $\begin{array}{l}\text { Anemia }(53,1 \%), \\
\text { neutropenia }(2,8 \%), \\
\text { trombositopenia } \\
(6,9 \%), \text { peningkatan } \\
\text { SGOT }(53,1 \%), \\
\text { peningkatan SGPT } \\
(54,5 \%), \text { ruam kulit } \\
(69,7 \%), \text { muntah } \\
(13,1 \%), \text { loose motions } \\
(46,2 \%), \text { febrile } \\
\text { neutropenia }(0,7 \%)\end{array}$ & 3 \\
\hline & & & 141 & $\begin{array}{l}\text { Pemetreksed } \\
\left(500 \mathrm{mg} / \mathrm{m}^{2}\right) \\
\text { dan carboplatin } \\
\text { (AUC 5) }\end{array}$ & & & $\begin{array}{c}5,6 \\
\text { bulan }\end{array}$ & $\begin{array}{c}22,6 \\
\text { bulan }\end{array}$ & $\begin{array}{l}\text { Anemia }(78,7 \%), \\
\text { neutropenia }(37,6 \%), \\
\text { trombositopenia } \\
(40,4 \%) \text {, peningkatan } \\
\text { SGOT }(40,4 \%), \\
\text { peningkatan SGPT } \\
(51,1 \%), \text { ruam kulit } \\
(28,4 \%), \text { muntah } \\
(24,1 \%), \text { loose motions } \\
(27,7 \%), \text { febrile } \\
\text { neutropenia }(8.5 \%)\end{array}$ & \\
\hline
\end{tabular}


interpretasi bukti perkembangan penyakit. ${ }^{11}$ Akan tetapi, pada penelitian First-SIGNAL diketahui bahwa PFS gefitinib tidak lebih baik dibandingkan kombinasi gemsitabin dengan sisplatin pada pasien yang tidak pernah merokok, walaupun pada penelitian IPASS gefitinib memiliki PFS yang lebih lama pada pasien yang tidak merokok dibandingkan dengan kemoterapi. Hal ini disebabkan pada penelitian First-SIGNAL, siklus pemberian kemoterapi berbasis platinum cukup banyak yaitu 9 siklus, sedangkan uji klinis yang telah banyak dilakukan sebelumnya biasanya hanya mengizinkan 4-6 siklus kemoterapi berbasis platinum. ${ }^{12}$ Pada uji fase acak III sebelumnya juga ditunjukkan bahwa durasi pengobatan yang lebih lama menunjukkan pengobatan yang lebih efektif, sehingga kemungkinan hal tersebut berkontribusi dalam perpanjangan PFS pada kemoterapi berbasis platinum. ${ }^{18,19}$

Efikasi gefitinib juga tidak lebih baik dari afatinib pada percobaan head to head LuxLung 7. Mekanisme kerja afatinib yang dapat memblokade ErbB secara irreversible lebih efektif dibanding penghambatan EGFR secara reversible pada gefitinib dalam pengobatan NSCLC dengan mutasi EGFR. Mekanisme aksi afatinib yang lebih luas dan irreversible dapat mengakibatkan kontrol tumor yang lebih baik sehingga dapat memperlama PFS maupun OS pasien NSCLC dengan mutasi EGFR. ${ }^{16}$

Pada hasil uji coba open-label fase acak 3 (Lux-Lung 6), afatinib secara signifikan $(p<0,0001)$ mampu menunda perkembangan NSCLC mutasi EGFR pada pasien Asia, hal ini dilihat dari PFS afatinib yang lebih lama dibandingkan kemoterapi. Penundaan pada perkembangan penyakit ini dibuktikan dengan adanya perbaikan untuk titik akhir (secondary endpoint) seperti respon objektif, pengendalian penyakit, dan dari hasil laporan pasien bahwa afatinib memiliki kemampuan dalam mengatasi gejala yang berhubungan dengan kanker paru yang lebih baik apabila dibandingkan kemoterapi berbasis platinum. ${ }^{15}$ Kepatuhan dalam pengobatan yang besar juga dapat menekan perkembangan penyakit dan dapat meningkatkan kualitas hidup dan kelangsungan hidup. ${ }^{20}$ Kelangsungan hidup secara keseluruhan pada afatinib tidak lebih unggul dibandingkan kemoterapi berbasis platinum, hal ini disebabkan pada Lux-Lung 6, data kelangsungan hidup secara keseluruhan belum matang pada saat dilakukan analisis. ${ }^{15}$ Dari hasil yang diperoleh pada penelitian sebelumnya, baik afatinib maupun gefitinib menunjukkan perbedaan kelangsungan hidup secara keseluruhan yang tidak begitu lebih baik jika dibandingkan kemoterapi berbasis platinum. ${ }^{10,12,13}$

Golongan TKIs secara umum memiliki toksisitas yang dapat ditoleransi. Kejadian toksisitas pada suatu obat dapat memengaruhi pemulihan pasien serta berdampak terhadap besar pembiayaan pada pengobatan pasien. ${ }^{21}$ Pada percobaan NEJ002, gefitinib memiliki perbaikan gejala yang cepat dan toksistas yang rendah. Efek samping yang paling umum dilaporkan yaitu ruam dan diare. ${ }^{10,13}$ Gefitinib dapat meningkatkan perkembangan penyakit interstitial paru sehingga dapat menyebabkan kematian, namun dengan tingkat kejadian yang rendah. Selain itu, gefitinib juga dapat menyebabkan infeksi paru yang merupakan salah satu bentuk reaksi obat yang tidak dikehendaki. ${ }^{12,22}$ Afatinib mempunyai efek samping yang sama dengan gefitinib, namun afatinib mempunyai efek samping diare dan ruam yang lebih tinggi dibanding gefitinib. ${ }^{16}$ Pengurangan dosis dan adanya pengelolaan efek samping dapat mengurangi kejadian efek samping. Selain itu, peran dari tenaga medis (baik dokter maupun apoteker) dalam melakukan monitoring respon terapi juga dibutuhkan dalam mengatasi efek samping yang timbul. ${ }^{16,23}$ Pada percobaan Lux-Lung 6, pengelolaan efek samping yang dibuat secara sistematis bermanfaat dalam pengobatan dan memaksimalkan efikasi pada afatinib. ${ }^{15}$ 
Keterbatasan dalam review ini adalah review ini hanya memberi informasi efikasi afatinib maupun gefitinib berdasarkan titik akhir ko-primer (endpoint coprimary) yaitu PFS dan OS pasien serta profil keamanan pasien NSCLC dengan mutasi EGFR, tetapi tidak terdapat informasi efikasi berdasarkan titik akhir sekunder (endpoint secondary) lain seperti tingkat respon objektif, proporsi pasien yang mencapai pengendalian penyakit, pengurangan gejala, serta kualitas hidup. Hal ini karena tidak semua penelitian yang telah ditinjau menyajikan data tersebut dan pengukuran kualitas hidup pada pasien juga menggunakan instrumen yang berbeda-beda. Pemeriksaan status mutasi pasien juga tidak dijelaskan karena pemeriksaan status mutasi tidak sepenuhnya dilakukan oleh studi aslinya dan pemeriksaannya menggunakan instrumen yang berbeda-beda, sehingga informasi terkait pemeriksaan mutasi EGFR menjadi terbatas. Selain itu, penelitian ini hanya menggunakan studi yang tersedia teks lengkapnya sehingga mempersempit cakupan jumlah artikel yang relevan untuk ditinjau. Akan tetapi, sejauh pengetahuan kami, pembahasan terkait efikasi afatinib dan gefitinib secara komprehensif belum ditemukan sehingga hal ini menjadi kekuatan pada artikel ini. Beberapa review yang sebelumnya telah dilakukan terbatas pada efikasi golongan TKIs secara keseluruhan, oleh karena itu, review ini diharapkan dapat menambah ilmu pengetahuan dan menjadi salah satu referensi bagi tenaga medis atau pemangku kebijakan dalam pemilihan terapi pada pasien NSCLC dengan mutasi EGFR.

\section{Simpulan}

Afatinib dan gefitinib memberikan efikasi yang lebih baik dibandingkan kemoterapi. Akan tetapi, afatinib memiliki efikasi yang lebih unggul dibandingkan gefitinib dalam pengobatan lini pertama pada pasien nonsmall cell lung cancer dengan mutasi EGFR.

\section{Pendanaan}

Penelitian ini dilakukan tanpa bantuan atau hibah dari manapun

\section{Konflik Kepentingan}

Seluruh penulis menyatakan tidak terdapat potensi konflik kepentingan dengan penelitian, kepenulisan (authorship), dan atau publikasi artikel ini.

\section{Daftar Pustaka}

1. Ferlay J, Soerjomataram I, Dikshit R, Eser S, Mathers C, Rebelo M, et al. Cancer incidence and mortality worldwide: Sources, methods and major patterns in GLOBOCAN 2012. Int J Cancer. 2015; 136(5):E359-86. doi: 10.1002/ijc.29210.

2. Chouaid C, Dujon C, Do P, Monnet I, Madroszyk A, Le Caer H, et al. Feasibility and clinical impact of re-biopsy in advanced non small-cell lung cancer: A prospective multicenter study in a realworld setting (GFPC study 12-01). Lung Cancer. 2014;86(2):170-3. doi: 10.1016/j. lungcan.2014.08.016.

3. Shi Y, Li J, Zhang S, Wang M, Yang S, Li N, et al. Molecular epidemiology of egfr mutations in asian patients with advanced non-small-cell lung cancer of adenocarcinoma histology-mainland China subset analysis of the pioneer study. Chai KX, editor. PLOS ONE. 2015;10 (11): e0143515. doi: 10.1371/journal.pon e. 0143515 .

4. Ettinger DS, Govindan R, Martins R. NCCN Guidelines. 2017.

5. Chi A, Remick S, Tse W. EGFR inhibition in non-small cell lung cancer: current evidence and future directions. Biomark Res, 2013 [diunduh 30 April 2019]. Tersedia dari: https://biomarkerres.biome dcentral.com/articles/10.1186/2050-777 


\section{1-1-2}

6. Solca F, Dahl G, Zoephel A, Bader G, Sanderson M, Klein C, et al. Target binding properties and cellular activity of afatinib (BIBW 2992), an irreversible ErbB family blocker. J Pharmacol Exp Ther. 2012;343(2):342-50. doi: 10.1124/ jpet.112.197756.

7. Ellis PM, Coakley N, Feld R, Kuruvilla $\mathrm{S}$, Ung YC. Use of the epidermal growth factor receptor inhibitors gefitinib, erlotinib, afatinib, dacomitinib, and icotinib in the treatment of non-small-cell lung cancer: A systematic review. Curr Oncol. 2015; 22(3):e183-215. doi: 10.3747/co.22.2566.

8. Zhang WQ, Li T, Li H. Efficacy of EGFR tyrosine kinase inhibitors in nonsmall-cell lung cancer patients with/ without EGFR-mutation: Evidence based on recent phase III randomized trials. Med Sci Monit. 2014;20:2666-76. doi: 10.12659/MSM.892476

9. Jadad AR, Moore RA, Carroll D, Jenkinson C, Reynolds DJM, Gavaghan DJ, et al. Assessing the quality of reports of randomized clinical trials: Is blinding necessary? Control Clin Trials. 1996;17(1):1-12. doi: 10.1016/0197-245 6(95)00134-4

10. Mok TS, Wu Y-L, Thongprasert S, Yang C-H, Chu D-T, Saijo N, et al.Gefitinib or carboplatin-paclitaxel in pulmonary adenocarcinoma. N Engl J Med. 2009; 361(10):947-57. doi: 10.1056/NEJMoa0 810699.

11. Mitsudomi T, Morita S, Yatabe Y, Negoro S, Okamoto I, Tsurutani J, et al. Gefitinib versus cisplatin plus docetaxel in patients with non-small-cell lung cancer harbouring mutations of the epidermal growth factor receptor (WJTOG3405): An open label, randomised phase 3 trial. Lancet Oncol. 2010;11(2):121-8. doi: 10. 1016/S1470-2045(09)70364-X.

12. Han JY, Park K, Kim SW, Lee DH,
Kim HY, Kim HT, et al. First-SIGNAL: First-line single-agent iressa versus gemcitabine and cisplatin trial in neversmokers with adenocarcinoma of the lung. 2012;30(10):1122-8. doi: 10.1200/J CO.2011.36.8456.

13. Inoue A, Kobayashi K, Maemondo M, Sugawara S, Oizumi S, Isobe $\mathrm{H}$, et al. Updated overall survival results from a randomized phase III trial comparing gefitinib with carboplatin-paclitaxel for chemo-naïve non-small cell lung cancer with sensitive EGFR gene mutations (NEJ002). Ann Oncol. 2013;24(1):54-9. doi: 10.1093/annonc/mds214

14. Patil VM, Noronha V, Joshi A, Choughule AB, Bhattacharjee A, Kumar R, et al. Phase III study of gefitinib or pemetrexed with carboplatin in EGFR-mutated advanced lung adenocarcinoma. ESMO Open. 2017;2(1):000168. doi: 10.1136/es moo pen-2017-000168

15. Wu YL, Zhou C, Hu CP, Feng J, Lu S, Huang $Y$, et al. Afatinib versus cisplatin plus gemcitabine for first-line treatment of Asian patients with advanced nonsmall-cell lung cancer harbouring EGFR mutations (LUX-Lung 6): An open-label, randomised phase 3 trial. Lancet Oncol. 2014;15(2):213-22. doi: 10.1016/S14702045(13)70604-1.

16. Park K, Tan E-H, O’Byrne K, Zhang L, Boyer M, Mok T, et al. Afatinib versus gefitinib as first-line treatment of patients with EGFR mutation-positive non-smallcell lung cancer (LUX-Lung 7): A phase 2B, open-label, randomised controlled trial. Lancet Oncol. 2016;17(5):577-89. doi: 10.1016/S1470-2045(16)30033-X.

17. Paz-Ares L, Tan E-H, O’Byrne K, Zhang L, Hirsh V, Boyer M, et al. Afatinib versus gefitinib in patients with EGFR mutationpositive advanced non-small-cell lung cancer: Overall survival data from the phase IIb LUX-Lung 7 trial. Ann Oncol. 
2017;28(2):270-7. doi: 10.1093/annonc/ mdw611.

18. Park JO, Kim SW, Ahn JS, Suh C, Lee JS, Jang JS, et al. Phase III trial of two versus four additional cycles in patients who are nonprogressive after two cycles of platinum-based chemotherapy in non small-cell lung cancer. J Clin Oncol. 2007;25(33):5233-9. doi: 10.1200/JCO.2 007.10 .8134

19. Lima JP da SN, Santos LV dos, Sasse EC, Sasse AD. Optimal duration of firstline chemotherapy for advanced nonsmall cell lung cancer: A systematic review with meta-analysis. Eur J Cancer. 2009;45(4):601-7. doi: 10.1016/j.ejca.20 08.11.006.

20. Silva DI, Ceccato M das GB, Silveira MR, Miranda SS, Maria Gomes R, Haddad JPA, et al. Predictors of mortality among individuals with tuberculosis and human immunodeficiency virus coinfection at a reference center in southeastern brazil: A retrospective cohort study. J Young
Pharm. 2018;10(4):476-80. doi: 10.5530/ jyp.2018.10.103

21. Singh H, Paramjeet Singh R, Singh B, Kaur Tiwana K. Exploring troublesome symptom and problems experienced by cancer patients undergoing chemotherapy. J Young Pharm. 2016;8(3):220-4. doi: 10. 5530/jyp.2016.3.9

22. Sunil Bellare P, Ashwin K, Prakash PU $\mathrm{S}$, Vinaykumar S, Kb R. A retrospective evaluation of adverse drug reactions due to cancer chemotherapy in a tertiary care hospital in south india. J Young Pharm. 2016;8(3):251-4. doi: 10.5530/jyp.2016. 3.14

23. Noviyani R, Suwiyoga K, Puspa I, Budiana N, Tunas K. Evaluasi nilai antigen squamous cell carcinoma pasien kanker serviks sel skuamosa stadium II B-III b yang menerima kemoterapi bleomisin, oncovin ${ }^{\circledR}$, mitomisin, dan cisplatin. Indones J Clin Pharm. 2015;4(2):106-12. doi: 10.15416/ijcp.2015.4.2.106 